\title{
DISCOURSES OF JUSTICE AMONG INTERNALLY DISPLACED PERSONS
}

УДК 159.923.2

DOI https://doi.org/10.32843/2663-

5208.2020.20.41

\section{Зімовін О.І.}

к.психол.н.,

доцент касредри прикладної психології Харківський національний університет імені В.Н. Каразіна

\section{Літвякова В.ю.}

студентка IV курсу фракультету психології

Харківський національний університет імені В.Н. Каразіна

\begin{abstract}
У статті представлено результати дослідження справедливості як дискурсивної конструкції у внутрішньо переміщених осіб. $B$ основу дослідження покладено дискурсивну психологію як особливу теоретико-методологічну перспективу, яка зосереджена на дослідженні конструювання психічного в повсякденному мовленні. Для збору даних використано напівструктуроване інтерв'ю, у якому респондентам ставили запитання про розуміння справедливості загалом, а також справедливості окремих дій і подій, зокрема вимушеного переміщення, характеристик справедливої людини тощо. Усі інтерв'ю записані за допомогою диктофона, а потім транскрибовані з використанням спеціальної системи. У дослідженні взяли участь 30 осіб, які мають статус внутрішньо переміщених, серед них - 11 чоловіків і 19 жінок віком від 18 до 50 років. Здійснено рандомізований відбір учасників. Достовірність дослідження забезпечувалася методичною та дослідницькою тріангуляцією. Визначено інтерпретативні репертуари, які використовуються внутрішньо переміщеними особами в конструюванні справедливості (перелічено в порядку зниження частоти використання): «справедливість як відповідний відгук» (респонденти чекають, що отримають нагороду за свої заслуги, або ж покарання - за помилки, тобто результат відповідає зробленому внеску), нормативний репертуар (справедливість - че певний закон, вона належить до загальних суспільних норм, яких варто дотримуватися), емоційний репертуар (коли мені добре - це справедливо, тобто розуміння справедливості спирається на суб'єктивні, емоційні переживання), надприродний репертуар (справедливість визначається вищими силами), фрілософрсько-абстрактний репертуар (справедливість неможливо або складно визначити), нігілістичний репертуар узагалі заперечує справедливість, у ньому вона відкидається, розглядається як неможлива.
\end{abstract}

Ключові слова: справедливість, дискурсивна психологія, дискурс, інтерпретативні репертуари, внутрішньо переміщені особи.

The article presents the results of the study of justice as a discursive construction among internally displaced persons. The research is based on discursive psychology as special theoretical and methodological perspective, which focuses on the study of the construction of the mental in everyday communication. A semi-structured interview was used to collect data, in such interview respondents were asked about their understanding of justice in general, as well as the justice of individual actions and events, including forced displacement, the characteristics of a just person, and others aspects. All interviews were recorded on a dictaphone and then transcribed using a special system. The study involved 30 people who have the status of internally displaced persons. Among them are 11 men and 19 women aged 18 to 50 years. Random selection of participants was performed. The reliability of the study was ensured by methodical and research triangulation. Interpretive repertoires used by internally displaced persons in constructing justice are identified (listed in descending order of use): "justice as an appropriate response" (respondents expect to be rewarded for their merits or punished for mistakes, i.e. the result corresponds to the made contribution), normative repertoire (justice is a certain law, it refers to the general social norms that must be followed), emotional repertoire (when I'm good - it's fair, i.e. understanding justice is based on subjective, emotional experiences), supernatural repertoire (justice determined by higher forces), philosophical-abstract repertoire (justice is impossible or difficult to define), nihilistic repertoire generally denies justice, it is rejected, considered impossible.

Key words: justice, discursive psychology, discourse, interpretive repertoires, internally displaced persons.
Постановка проблеми. Умови сучасного суспільства, яке $є$ дуже конкурентним, орієнтованим на індивідуалістичність і споживацтво, призвели до розмивання й навіть утрати значущості основоположних принципів справедливості, світом усе більше «керує» несправедливість: гроші, влада, війна. Нинішня ситуація в Україні змусила велику кількість людей полишити власні домівки на тимчасово окупованих територіях, зіткнула їх із неймовірно складними переживаннями та призвела до неминучих травм. Війна зачепила й навіть зруйнувала всі аспекти життя цих людей, яких зараз ми називаємо внутрішньо переміщеними особами, тому вони вимушені були вибудовувати заново власний фізичний (нова домівка, їжа, безпека), соціальний (нові кон- такти, робота) і психологічний (перебудова ідентичності, складні емоційні стани) простір. Зважаючи на це, постає питання: як люди, що опинилися в цих жахливих обставинах, конструюють справедливість сьогодні? Чи можуть вони спиратися на такий важливий принцип соціального співіснування, чи вони переконані в несправедливості соціальної загалом, людської екзистенції? Чи можна, досліджуючи ці аспекти, допомогти цим людям? Сама наявність запитань указує на соціальну актуальність досліджень конструювання справедливості внутрішньо переміщеними особами.

Великий інтерес до такого фундаментального поняття, як справедливість, проявляється в працях учених різних галузей знань, і в художній літературі, і в повсякденності. Це 
неминуче призводить до ускладнення та неоднозначності цього концепту. Серед відомих дослідників, які цікавилися феноменом справедливості, - Дж. Ролз, Дж. Адамс, М. Лернер, Ж. Піаже, М. Слюсаревський, О. Гулевич та ін. Усі вони мали різні, деколи вкрай протилежні погляди та вивчали різні аспекти цього поняття, проте можна виділити думку, яка їх, безумовно, єднає: питання про справедливість найчастіше постає там, де вона порушується.

Так як справедливість $є$ соціальною категорією та відіграє основоположну роль у регуляції соціальних відносин, в основу дослідження покладено особливу теоретико-методологічну перспективу - дискурсивну психологію (Дж. Поттер, М. Уезерелл), яка $є$ напрямом соціального конструкціонізму та описує й пізнає психічні феномени в процесі соціальної взаємодії через мову.

Теоретик дискурсивної психології Р. Харре [14, с. 92] уважав, що буденне мовлення є найбільш важливим об'єктом, за допомогою якого можливо досліджувати людську психіку. Тож, ми вважаємо за необхідне звернутися до тих вимірів справедливості, які безпосередньо пов'язані з вивченням мовної практики, дискурсу й комунікації, та виявити особливості конструювання цього поняття внутрішньо переміщеними особами - людьми, які опинилися в ситуації крайньої несправедливості.

Аналіз останніх досліджень і публікацій. Дискурсивна психологія є напрямом соціальної психології, видом дискурс-аналізу, що утворився в 1980-90-х роках під час другої когнітивної революції, коли стався «дискурсивний поворот» у соціальних науках. Дж. Поттер та М. Везерел [5, с. 181], одні зі співзасновників дискурсивної психології, сутність її та основну мету вбачали в пізнанні психічних феноменів у процесі соціальних інтеракцій через мову, чим ознаменували відхід від когнітивістського погляду на психічні процеси й категорії як виключно «внутрішні».

Дискурсивна психологія $€$ спорідненою із соціальним конструкціонізмом - теорією, яка наголошує на визнанні першорядної ролі дискурсу та відносин між людьми в конструюванні ними світу і власного Я, необхідності відмови від уявлення про загальні абсолютні істини, адже стандарти поведінки та психологічні процеси прив'язані до культури й історії конкретних спільнот, а також закликає до взаємозбагачення різних дискурсів, демократизації та соціального перетворення свідомості людей [8, с. 201]. Конструкціонізм протиставляється традиційному когнітивному підходу до розуміння знання, де воно постає лише як продукт сприйняття й раціонального мислення окремого суб'єкта. Тобто критикується недооцінка значення соціальної ситуації, у якій відбувається процес пізнання людиною навко- лишнього світу, через що втрачається дуже важливий аспект пізнання - конструювання соціального світу, на чому в працях наголошував К. Джерджен [3, с. 64]. Знання не може бути розглянуто як предмет індивідуального володіння, зосереджений у межах людського розуму, а має розумітися як продукт спільної діяльності людей. Отже, усе, що різні люди вважають реальним, цінним, правильним, гідним наукового або духовного осягнення, конструюється за допомогою мови в стосунках з іншими людьми.

Подібних поглядів дотримується й дискурсивна психологія, проте ії̈ представники (Дж. Поттер, М. Везерелл, М. Білліг та ін.) вирішили відмовитися від вивчення абстрактних структур мови. Вони демонструють, що мовні дії вбудовані в соціальний контекст, їх значення залежить від способів їх уживання [7, с. 51]. Тобто певне висловлювання завжди матиме конкретну орієнтацію та ситуаційну значущість. Згідно з позицією Я. Паркера, дискурсивна психологія пропонує інтегративний холістичний підхід замість штучного поділу мови та психічних процесів; вона заперечує ефективність розділення простору психології на психіку індивідів з наявними феноменами й дослідника з його науковим досвідом і набором методологічних інструментів [9, с. 13].

Украй значущою для дискурсивних практик $€$ культурно-історична теорія Л. Виготського [2]. По-перше, завдяки його науковим доробкам визнано важливість особливостей соціальної ситуації розвитку дитини та загалом впливу соціуму на людину. По-друге, він висунув ідею цілісності людини з культурно-історичним простором, у якому вона живе. По-третє, його «внутрішнє мовлення» як інтеріоризована форма діалогу демонструє першочерговість спілкування для формування мислення, що знову відсилає нас до критики когнітивістського розбивання психічних процесів на окремі складники.

Поняття справедливості існує в міждисциплінарному просторі, через що має великий діапазон визначень і постійно обговорюється. Соціально-психологічне розуміння справедливостітакожскладаєтьсязмножинитеоретичних уявлень. Деякі з них добре співіснують, доповнюючи одне одного, інші значно відрізняються.

Найбільш популярною можна назвати теорію еквівалентної справедливості Дж. Адамса [13, с. 436], у якій стверджується, що індивід постійно суб'єктивно співвідносить отримане винагородження із затраченими зусиллями й порівнює з тим, як оцінені аналогічні дії та заслуги інших. Інший відомий дослідник справедливості Дж. Ролз [10], на відміну від Дж. Адамса, не наділяв справедливість характеристиками внутрішнього почуття, а вважав її першою чеснотою суспільних інститутів, яка 
не допускає, щоб утрата свободи одними була виправдана більшими благами інших; щоб одні користувалися перевагами за рахунок інших.

М. Слюсаревський $[11$, с. 3] розглядає справедливість не всупереч, проте з іншого боку - як одну з усезагальних цінностей. У його концепції ціннісна регуляція поведінки $є$ ознакою особистісної зрілості, а рівень цінності справедливості як мотиваційної структури забезпечує прагнення особистості визначати характер і спрямованість своїх вчинків у нормативних ситуаціях відповідно до внутрішніх суб'єктивних сенсів, якими вона наділяє чинні норми, допомагає оцінці конкретних вчинків як прийнятних чи не прийнятних стосовно системи ціннісних норм.

В. Бучко [1, с. 48-49] найбільше за інших зосередився на емоційно-оцінному сприйманні справедливості, що, на його думку, формується індивідом на основі його вроджених і набутих на момент сприймання особливостей, взаємодії із зовнішнім середовищем, властивостями сприйняття.

О. Гулевич [12, с. 292] у працях зосереджується на особливостях поведінкових реакцій індивіда, що представлені як частини єдиного процесу оцінки ситуації як справедливої або несправедливої. Спочатку відбувається оцінка справедливості/несправедливості події, пошук винуватця несправедливості й оцінка ступеня його відповідальності, потім вибір стратегії реагування. Останнє - це реалізація обраного способу поведінки.

Окрім цього, багато дослідників вивчають феноменологічні прояви справедливості. М. Лернеру [15], який виходив з уявлення про справедливість як «кармічне» утворення, вдалося емпірично виявити феномен «віри в справедливий світ». Його сутність у тому, що особистість, безумовно, визнає справедливість властивістю оточення, залишаючись глибоко переконаною, що зло та добро, випадкові події тощо належить моральним заслугам людей і груп, із якими вони трапляються.

Різноманітність уявлень і широкий діапазон досліджень, тим не менше, майже не зачіпляє питання комунікативного аспекту справедливості, її виявлення в безпосередньому житті людини. Більшість теорій ґрунтується або на абстрактних ідеальних концептах справедливості, або розглядає певні виявлені особливості й механізми. Отже, ми вважаємо доцільним і цікавим дослідити дискурсивне конструювання справедливості особливою групою людей - внутрішньо переміщеними особами, які зазнали глибокої несправедливості.

Постановка завдання. Метою статті $€$ характеристика дискурсивного конструювання справедливості у внутрішньо переміщених осіб.
Виклад основного матеріалу дослідження. Метод. У конструюванні справедливості найбільшу цікавість і цінність для нас становили саме особистісні уявлення респондентів і ті значення та сенси, які вони вкладають в опис цього поняття, тому нами обраний шлях якісного дослідження. Теоретико-методологічною основою для проведення дослідження стала дискурсивна психологія, основні положення якої ми розглядали вище, а головним методом збору даних послугувало напівструктуроване інтерв'ю, метою якого було виявлення інтерпретативних репертуарів справедливості. Цей метод дає змогу наблизитися до звичайного буденного спілкування, а саме в повсякденному мовленні можна яскраво побачити, що для людей значить поняття «Справедливість», для чого й у зв'язку з якими ситуаціями вони ним користуються.

Інтерпретативний репертуар - центральне робоче поняття дискурсивної психології, яке використовується замість більш широкого та багатозначного концепту «дискурс». Під інтерпретативним репертуаром Дж. Поттер та М. Уезерелл розуміють "системи термінів, що періодично використовуються, які характеризують та оцінюють дії, події та інші явища. ... Часто репертуар формується навколо специфічних метафор або фігур мови» [16, с. 90].

Наведемо приклади запитань, які слугували основою для бесіди респондента та інтерв'юера: скажіть, будь ласка, як Ви розумієте, що таке справедливість?; Чи можете навести конкретні приклади, коли з Вами поводилися справедливо і несправедливо? Як Ви визначили, що саме це слід вважати справедливим або несправедливим?; Чи бувало таке, що Ви поводилися 3 кимось справедливо, несправедливо? Що дає змогу вважати свою поведінку саме такою?; розкажіть, будь ласка, про свій переїзд із Донбасу (у якому році? як відбувався?); Що ця подія означає для Вас?; Як Ви вважаєте цей вимушений переїз - справедливий? У чому його несправедливість?; Скажіть, будь ласка, на Ваш погляд, світ загалом справедливий? Як Ви це розумієте?

Нагадаємо, що мова йде про напівструктуроване інтерв'ю, отже, запитання могли змінюватися та доповнюватися. Зазначимо також, що респонденти загалом російськомовні, тому запитання ним ставилися російською мовою. Весь процес інтерв'ю записувався на диктофон, а потім транскрибувався за допомогою спеціальної системи. У статті відповіді респондентів перекладено українською мовою, щоб забезпечити цілісність тексту.

В основу дослідження покладено якісні методи, проте, погоджуючись із думкою, що протиставлення якісних і кількісних методів $€$ популярною, але непродуктивною стра- 
тегією, для посилення наукової значущості, достовірності й повноти результатів дослідження ми вирішили застосувати методичну тріангуляцію: результати, отримані якісно, доповнюються також кількісними показниками. Для отримання кількісних показників застосовано методику «Шкала базисних переконань» Р. Янов-Бульман - опитувальник, заснований на когнітивній концепції базових переконань особистості, в адаптації М. Падуна, А. Котельникової.

Для статистичної обробки даних ми застосували частотний аналіз, щоб охарактеризувати тенденції в якісних даних, а також інші методи описової статистики.

Варто зазначити, що дискурсивні психологи впевнені в тому, що будь-яка істина народжується у взаємодії, тому нами реалізовано також дослідницьку тріангуляцію. Залучення до аналізу інтерв'ю більше одного дослідника слугує для зменшення ймовірності нелогічних висновків, продиктованих особливостями сприйняття окремої людини. Підсумки аналізу одного й того ж інтерв'ю двома дослідниками, які сягають певної згоди, повинні також підвищити достовірність дослідження.

Вибірка. У дослідженні взяли участь 30 осіб, що мають статус внутрішньо переміщених, серед них - 11 чоловіків і 19 жінок віком від 18 до 50 років (середній вік - 29,2). Для підвищення надійності дослідження здійснено рандомізований відбір учасників за допомогою методу випадкових чисел, тому вибірку становили люди, які належать до різних вікових і соціальних груп, займаються різноманітною професійною діяльністю тощо.

Метою дослідження виокремлення інтерпретативних репертуарів, тому при обробці

\section{Відомості про учасників інтерв'ю}

Таблиця 1

\begin{tabular}{|c|c|c|c|}
\hline Респондент & Стать & Biк & Рід діяльності \\
\hline № 1 & Жіноча & 20 & Студент-культуролог, філософський факультет \\
\hline № 2 & Жіноча & 45 & Військовослужбовець (картограф) \\
\hline № 3 & Жіноча & 20 & Музикант, студент консерваторії, відділення фортепіано \\
\hline № 4 & Жіноча & 48 & Педагог музикальної школи, піаністка \\
\hline № 5 & Чоловіча & 22 & Студент консерваторії, відділення фортепіано \\
\hline № 6 & Жіноча & 21 & Студент-психолог \\
\hline № 7 & Чоловіча & 47 & Водій \\
\hline № 8 & Жіноча & 19 & Студент-психолог \\
\hline № 9 & Жіноча & 35 & Психотерапевт \\
\hline № 10 & Жіноча & 19 & Студент-філолог (перекладач з англійської та німецької) \\
\hline № 11 & Чоловіча & 50 & Зварювальник, тимчасово безробітний \\
\hline № 12 & Жіноча & 23 & Музикант-трубач \\
\hline № 13 & Жіноча & 27 & Домогосподарка \\
\hline № 14 & Жіноча & 21 & Студент за спеціальністю системний аналіз \\
\hline № 15 & Жіноча & 22 & Студент-філолог (перекладач з китайської) \\
\hline № 16 & Жіноча & 19 & Студент-біолог \\
\hline № 17 & Жіноча & 25 & Працює менеджером у магазині сирів і вин \\
\hline № 18 & Чоловіча & 34 & Бізнесмен \\
\hline № 19 & Жіноча & 25 & Туристичний гід \\
\hline № 20 & Чоловіча & 23 & Студент за спеціальністю системний аналіз \\
\hline № 21 & Чоловіча & 27 & Програміст \\
\hline № 22 & Жіноча & 49 & $\begin{array}{l}\text { Вихователь у дитячому саду, викладач дошкільної педаго- } \\
\text { гіки і психології }\end{array}$ \\
\hline № 23 & Чоловіча & 31 & Системний адміністратор \\
\hline № 24 & Чоловіча & 28 & Бізнесмен \\
\hline № 25 & Чоловіча & 23 & Студент-програміст \\
\hline № 26 & Жіноча & 43 & Педагог фортепіано \\
\hline № 27 & Чоловіча & 31 & Бізнесмен \\
\hline № 28 & Жіноча & 18 & $\begin{array}{l}\text { Студент за напрямком інформаційні системи і технології } \\
\text { проектування }\end{array}$ \\
\hline № 29 & Чоловіча & 38 & Економіст, бізнесмен \\
\hline № 30 & Жіноча & 24 & Викладач з музики, віолончелістка \\
\hline
\end{tabular}


інтерв'ю нас цікавили прийоми й терміни, до яких люди звертаються в конструюванні справедливості, сенси та характеристики, що формуються з цього, і способи поводження із цим конструктом.

За результатами аналізу інтерв'ю ми виділили шість інтерпретативних репертуарів провідних систем концептів, які з різною частотою зустрічаються в уявленнях респондентів про справедливість. Кожному з них присвоєно умовну назву, яка, на нашу думку, найбільш точно узагальнює сутність цього репертуару.

Репертуар, що зустрічається в кількості відповідей - у 73\% - можна назвати справедливість як відповідний відгук. Це розуміння справедливості певним чином відсилає до відомої всім ідеї класика, що за злочином обов'язково слідує покарання [4]. Також ідея дуже близька до поняття дистрибутивної справедливості - одного з двох видів справедливості, уведених ще Аристотелем [6, с. 89], яке в найбільш загальному сенсі полягає в розподіленні благ за гідністю - пропорційно заслугам. Цей спосіб розуміти справедливість використаний також Дж. Адамсом [13] у його теорії еквівалентної справедливості.

Так, у відповідях респондентів можна побачити, що справедливою буде вважатися лише та подія, де результат повністю релевантний зробленому внеску.

«Справедливо, коли твій внесок відповідає тому, що ти отримуєш у відповідь», - каже дівчина 20 років.

А чоловік 46 років уважає, що справедливість - це таке: «За якісь певні дії ти отримуєш чи то нагороду, чи то покарання, і це все відбувається під знаком того, що ти робиш».

Ми припускаємо, що такі уявлення можуть слугуватидлярегуляціїповедінкитазбереження мотивації, тобто люди намагаються заслужити на певні заохочення, блага, гарне ставлення, при цьому запобігають покаранню або незадовільному результату та поганому ставленню.

Цей конструкт часто використовується респондентами не лише для локальної оцінки подій, а для оцінки людини або ставлення до неї загалом, через що дотримання справедливості набуває визначальної сили у виборі життєвих стратегій.

«Ц (пр. = справедливість) якесь ставлення до людини в плані, що вона заслужила» (дівчина, 20 років).

Дуже яскраво цю точку зору виражає хлопець 22 років: «Світ настільки справедливий, наскільки ти справедливий до нього».

Нормативний інтерпретативний репертуар або справедливість як відповідність нормам і дотримання порядку. Поява цього репертуару зумовлена зверненням респондентів до таких термінів: «закон», «мораль», «чесність», «порядність», «правила». Цей репертуар знаходиться на другому місці за частотою: він зустрічався в 50\% відповідей, при цьому у $34,6 \%$ - у поєднанні зі справедливістю як відповідний відгук. Не дивно, що ці системи уявлень у людській свідомості переплітаються, адже дотримання морального або правового закону досить часто передбачає саме відплату по заслугах. Але взаємозв'язок не означає тотожність. Нормативний репертуар здебільшого спирається на зовнішні сили: справедливість повинна відповідати загальноприйнятим нормам, правилам, законам у тому суспільстві або групі, у якій існує кожний окремий індивід. Це означає певну варіативність норм справедливості. Те, що буде нормальним і порядним в африканському племені, може не збігатися чи навіть вступати в протиріччя з прийнятою нормою, наприклад, у Центральній Європі; справедливе за конституцією має небагато спільного зі справедливим у мафіозних організаціях. 3 одного боку, така справедливість відображає соціальні та культурно-історичні особливості суспільства, яке декларує її орієнтири і стандарти, а з іншого - народжується через комунікацію, певні домовленості між людьми в різних умовах та обставинах.

«Ось для когось це буде аморально й неправильно, а для когось це буде нормально і правильно. Тобто загальне поняття справедливості, як і загальне поняття моралі, не можуть бути єдині», - висловлюється жінка, 48 років.

«Справедливість - це існування згідно з нормами й законами того суспільства, у якому ти живеш ...» (чоловік, 34 роки).

Як уже зазначено, респонденти використовують справедливість як орієнтир певної правильності, на яку варто рівнятися, яка допомагає робити правильний вибір.

«Це поняття про те, як має бути. I про те, що буде, якщо порушувати це «має» (чоловік, 34 роки).

До того ж справедливість є антагоністом суб'єктивності, емоційної оцінки подій. Учасники дослідження, які використовують нормативний інтерпретативний репертуар, уважають: щоб чинити справедливо, необхідно дотримуватисяправилізаконів, відкидаючипри цьому власні почуття, вигоди, бажання, висновки, які не засновано на об'єктивних фактах.

Наприклад, дівчина 25 років каже: «Справедливо - це коли дія відповідає загальноприйнятим правилам і виконується неупереджено людством».

Наступним за частотою використання (у 46,1\% респондентів) став емоційний інтерпретативний репертуар, у якому справедливість загалом або справедливість певних подій не лише супроводжується, а визначається саме через емоційну оцінку. Загальноприйнятні правила й норми, раціональний аналіз відходять на другий план або 
взагалі відкидаються на користь задоволення бажань, інтересів і почуттів індивіда. Найчастіше це виражається в ідеї: «Справедливо те, що добре для мене».

Дівчина 21 року проводить своєрідну межу між поняттями «справедливо для всіх» і «справедливо для мене»: «... коли ти здавав не свою роботу в універі й отримував за неї погану оцінку, з одного боку, думав, що це справедливо, тому що це навіть не твоя робота, а з іншого: «Блін, я ж купив ідеальну роботу, чому в мене за неї неідеальна оцінка?» Це, напевно, випадок однакової і справедливості, і несправедливості для мене».

Отже, деякі респонденти свідомо відкидають те, що, на їхню думку, є правильним узагалі заради власного відчуття задоволення. Це зазначає й жінка 42 років: “Справедливий для самого себе або справедливий для когось це різні речі».

В інших випадках респонденти своє емоційне ставлення до ситуації видають за головний критерій справедливості, не визнаючи суб'єктивності такої позиції.

«Якщо мені захотілося вважати, що це справедливо, я буду вважати, що це справедливо, а якщо я не думаю, що це справедливо, тоді я буду вважати, що це несправедливо» (дівчина, 21 рік).

Але це не єдиний можливий варіант використання цього репертуару. Так як емоційна оцінка стає першочерговим і головним показником справедливості того, що відбувається, вона несе також регулятивну функцію, допомагає людині будувати чи корегувати свою поведінку. Емоційний стан і почуття можуть сигналізувати про те, чи була порушена справедливість з боку як самого суб'єкта, так і його оточення. Результати інтерв'ю демонструють, що часто усвідомлення несправедливості своїх дій приходить через неприємні почуття, такі як сором, провина, докори сумління. А розуміння, що щось відбулося справедливо або людина сама вчинила справедливо, викликається почуттями радості, задоволення, здорової гордості.

Жінка 45 років, відповідаючи на питання, що допомагає їй визначити власну несправедливість, відповіла: «Мене мучить совість!», а говорячи про визначення своїх справедливих дій, вона ж указує: “Ой, я собою пишаюся... Мені подобається це почуття...».

Наступним за частотою став надприродний репертуар, використаний 23\% учасників дослідження. Його головною особливістю $€$ розгляд справедливості як властивості «вищих сил», що керують і глобальними процесами на Землі, і локальним життям окремих індивідів. Як такі сили можуть виступати бог, карма, Всесвіт. Визначальна роль також може відводитися оточенню або природі.
«Може, усе повертається в кінці життя, тут уже мовби ваги - це така справа, не ми зважуємо, не нам вирішувати» (жінка, 48 років).

Цей репертуар добре виявлявся у відповідях на питання: «Хто може вирішувати, що справедливо, а що - ні?» та «Чи є світ справедливим?»

«Ну, особисто в моєму житті, хто може сказати, чи справедливо я живу? Тільки Бог» (жінка, 45 років).

«Я вважаю, світ сам розсудить. Доля» (дівчина, 21 рік).

Філософсько-абстрактний репертуар також проявився у 23\% відповідей. У його межах справедливість представляється дискусійним, багатогранним поняттям, чітке визначення якого просто неможливе: «Це як погода ... Долар по п'ять - класно, справедливо, по вісім - несправедливо, по тридцять ой, як класно, коли по вісім ... Справедливість поняття багатогранне ... Це не двічі два, не чітке математичне поняття, його не можна включити в якусь формулу» (жінка, 49 років).

Таке конструювання справедливості відрізняється від попередніх тим, що індивіди зазвичай надають відповіді у формі роздуму на задану тему, найчастіше апелюючи до філософії, намагаються розглянути поняття через призму різних точок зору, світогляду, ситуаційного контексту.

«Справедливість для мене - це певна ідеальна модель правильності» (дівчина, 20 років).

Цьому репертуару властиво використання туманних формулювань, запобігання чіткості й однозначності, нерідко суперечливість думок, що може зумовлюватися як власне невизначеністю позиції, так і свідомою відмовою від дотримування будь-яких «вузьких» поглядів.

«З тієї ж філософської точки зору після перегляду Гарвардських лекцій можу вас точно запевнити, що у філософії немає на це чіткої відповіді» (хлопець, 21 рік).

Характерним $€$ акцентування на тому, що справедливість - це соціальний конструкт, тобто може існувати лише в людському суспільстві. 3 чого випливає ідея суб'єктивності, ситуаційності, умовності поняття «справедливість».

«Є мільйони точок зору на справедливість, відповідно, хоч якийсь із них я буду задовольняти, отже, я - справедлива людина» (хлопець, 21 рік).

Останній, найрідший, інтерпретативний репертуар названий нігілістичним репертуаром і з'явився лише в 15,4\% учасників. Основна його сутність - у нерозумінні та запереченні поняття справедливості як такого. Також у цьому репертуарі артикулюється негативне ставлення до справедливості й нама- 


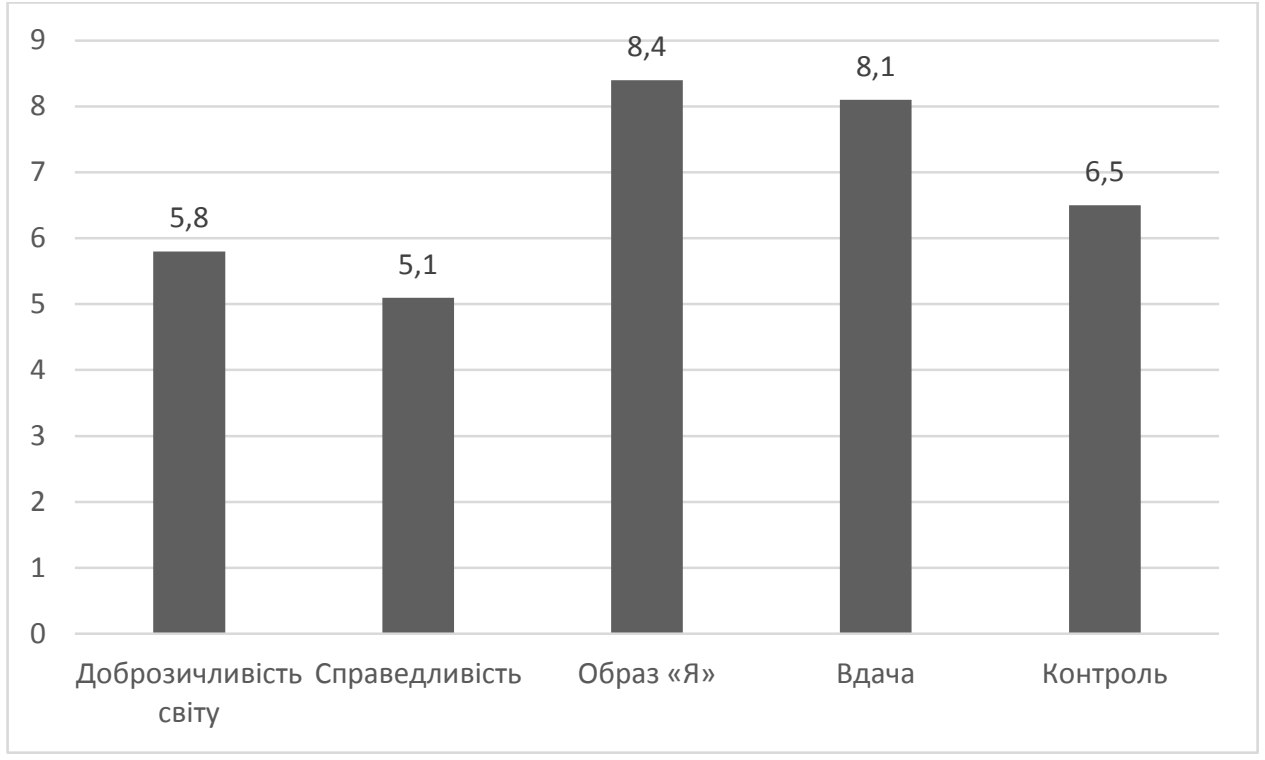

\section{Рис. 1. Вираженість базових переконань внутрішньо переміщених} осіб (середні значення)

гання спростувати їі, поставити під сумнів закони, правила й саму необхідність існування такого конструкта. Цікаво, що в 75\% нігілізм щодо справедливості поєднувався з попереднім, філософським репертуаром. Неможливість осягнути власний досвід справедливості/ несправедливості, здається, може відбиватися як у запереченні цього явища, так і у створенні хаотичної множини міркувань про нього.

«Ну, сказати, що $\epsilon$ якась справедлива людина, значить сказати, що є справедливість і несправедливість, а насправді же їх не існує. Ну, немає такого чіткого канону несправедливості й справедливості» (дівчина, 20 років).

Негативне ставлення найбільш проявляється в підозрах, що «недружелюбний» соціум створив справедливість, щоб контролювати людей і позбавити їх свободи, власної волі.

«Це (пр.: справедливість) досить, знаєте, controversial ... суперечливе питання. Є різні точки зору, і якоїсь однієї максимально адекватної немає», «Це $-x^{* \star *}$ я, якої ніколи не буде в цьому світі» (хлопець, 21 рік).

Наприклад, жінка 42 років дає такі відповіді: «Я не знаю, що таке справедливість», «Я думаю, справедливих (пр.: людей) не існує», «Справедливо - це ніколи».

Реалізуючи стратегію методичної тріангуляції, ми також використали опитувальник «Шкала базисних переконань» Р. Янов-Бульман (в адаптації М. Падуна, А. Котельникової). Середні показники вираженості базисних переконань внутрішньо переміщених осіб відображено в гістограмі (див. рис. 1)

Як бачимо, у наших респондентів саме вираженість переконання про справедливість $€$ найменшою серед усіх інших базових переко- нань. При цьому вона також менша за середнє стандартної десятки, яка використовується в методиці, і, відповідно, становить 5,5. Отже, кількісні показники також указують на те, що в результаті внутрішнього переміщення в певній кризі зниження опинилося переконання про справедливість. Ці показники підтверджують значущість дискурсів про справедливість, а також трішки пояснюють, чому таким розповсюдженим стає інтерпретативний репертуар «справедливість як відповідний відгук», адже справедливість у житті респондентів значно порушена.

Висновки 3 проведеного дослідження. З позицій дискурсивної психології в інтерв'ю внутрішньо переміщених осіб виокремлено 6 інтерпретативних репертуарів, які застосовуються ними з різною частотою для конструювання справедливості:

- репертуар «справедливість як відповідний відгук» артикулює справедливість як відплату й розподілення благ по заслугах, коли результат відповідає здійсненому внеску, цей репертуар є найбільш популярним у відповідях респондентів - 73\%;

- нормативний репертуар, який включає розуміння справедливості як звід певних норм, правил або законів, регульованих суспільством, зустрічається в 50\% відповідей;

- емоційний репертуар, у якому справедливість визначається через емоційну оцінку та підпорядковується суб'єктивним судженням людини, використовується і 46, 1\%;

- надприродний репертуар, який приписує справедливість властивостям «вищих сил», і філософсько-абстрактний репертуар, який представляє справедливість як дискусійне 
поняття, чітке визначення якого неможливе, зустрічається значно рідше - у 23\%;

- нігілістичний репертуар узагалі заперечує справедливість і є найрідшим - його використано в 15,4\% інтерв'ю.

Перспективи подальших досліджень ми вбачаємо, по-перше, у з'ясуванні зв'язків між конструюванням справедливості й певними психологічними особливостями внутрішньо переміщених осіб, наприклад, стилем прихильності, тривожністю, толерантністю до невизначеності, характерологічними особливостями тощо; по-друге, у порівнянні конструювання справедливості внутрішньо переміщеними особами з тими, хто не зазнав переміщення; і нарешті, по-третє, у розробленні психологічних/психотерапевтичних практик, які дадуть людям змогу переживати травмуючі та кризові події, мінімізуючи ту шкоду, які вони нам несуть.

\section{ЛІТЕРАТУРА:}

1. Бучко В.Б. Проблема справедливості: психологічний аспект. Психологія: реальність і перспективи. 2015. Вип. 4. С. 43-49.

2. Выготский Л.С. Психология развития человека. Москва : Смысл, Эксмо, 2004. 1136 с.

3. Джерджен К. Движение социального конструкционизма в современной психологии. Социальная психология: саморефрлексия маргинальности : хрестоматия. Москва, 1995. С. 63-64.

4. Достоевский Ф.М. Преступление и наказание. Москва : Издательство Юрайт, 2019. 408 с.

5. Йоргенсен М.В., Филлипс Л.Дж. Дискурс-анализ. Теория и метод. Харьков : Гуманитарный Центр, 2008. 352 c.
6. Кашников Б.Н. Концепция общей справедливости Аристотеля: Опыт реконструкции. Этическая мысль. 2001. Вып. 2. С. 89-118.

7. Макаров М.Л. Основы теории дискурса. Москва : ИТДГК «Гнозис», 2003. 280 с.

8. Морина Л.П. Дискурсивная психология: трансорормация понятий в рамках дискурс-аналитических исследований. Studia culturae. 2016. Вып. 4 (26). С. 201-207.

9. Паркер И. Психоаналитическая культура: психоаналитический дискурс в западном обществе. Ижевск : ERGO, 2013. 391 c.

10. Ролз Дж. Теория справедливости. Новосибирск : Издательство Новосибирского Университета, 1995. $514 \mathrm{C}$.

11. Слюсаревский М.М. Иллюзии и коллизии. Киев : Гнозис, 1998. 234 с.

12. Фальковська Л.М. Справедливість як предмет соціально-психологічного дослідження. Проблеми політичної психології та її роль у становленні громадянина Української держави : збірник наукових праць. 2011. Вип. 11. С. 290-299.

13. Adams J. S. Towards an understanding of inequity. Journal of Abnormal and Social Psychology. 1963. № 67 (5). P. 422-436.

14. Harré R. Positioning theory: moral dimensions of social-cultural psychology. In J. Valsiner (ed.) The Oxford Handbook of Culture and Psychology. New York : Oxford University, 2012. P. 191-206.

15. Lerner M.J. The justice motive: Where psychologists found it, how they lost it, and why they may not find it again. Personality and Social Psychology Review. 2003. № 4. P. 388-399.

16. Potter J., Wetherell M. Discourse and social psychology: beyond attitudes and behavior. London : Sage, 1987. 216 p. 